Janusz Nawrot ${ }^{1}$

Uniwersytet im. Adama Mickiewicza w Poznaniu, Polska

Wydział Teologiczny

\title{
O krok dalej w przybliżeniu słowa Bożego. Poznańscy bibliści w służbie orędzia Starego i Nowego Testamentu
}

\section{Wstęp}

Z okazji 100-lecia istnienia i działalności Uniwersytetu im. Adama Mickiewicza w Poznaniu można podsumować wkład Wydziału Teologicznego, istniejącego w strukturach uczelni równe 20 lat, w bogactwo form aktywności badawczej, dydaktycznej, połączonej z zaangażowaniem na rzecz wielkopolskiego środowiska społecznego. Specyfiką wydziału jest umiejętność pracy zarówno na niwie typowo naukowej i dydaktycznej, jak i społeczno-kościelnej, co wymaga sporych zasobów wiedzy i czasu, by umiejętnie łączyć wymogi pracy na uniwersytecie z postulatami życia Kościoła powszechnego, kierującego się w dobie obecnej przede wszystkim zasadami wypracowanymi przez II sobór watykański. Z tej racji przypomnieć w tym miejscu wypada kilka podstawowych punktów biblijnej odnowy soboru. W myśl Konstytucji Dei Verbum w części „O Piśmie Świętym w życiu Kościoła" (DV 21-25) są to: inicjatywy duszpasterskie archidiecezji poznańskiej promujące Pismo Święte pośród wiernych (DV 21), przekłady Pisma św. (DV 22), badanie i wykład Biblii w seminariach dla lepszego przygotowania księży do nauczania ludu oraz prowadzenie badań naukowych nad Pismem św. pod nadzorem Urzędu Nauczycielskiego Kościoła (DV 24), a wreszcie przepojenie teologii, kaznodziejstwa, katechezy, homiletyki i wszelkiego nauczania chrześcijańskiego słowem Bożym (DV 25).

Celem niniejszego artykułu jest zaznajomienie czytelnika z kilku doniosłymi przykładami realizacji zarówno naukowo-dydaktycznego posłannictwa Wydziału Teologicznego, jak i postulatów soborowych w tej materii. Pozwoli to doko-

${ }^{1}$ Ksiądz prof. dr hab. Janusz Nawrot — ur. w 1960 roku w Międzychodzie, woj. wielkopolskie; kapłan archidiecezji poznańskiej od 1985 roku; wykładowca WT UAM w Poznaniu; kierownik Zakładu Nauk Biblijnych; specjalizuje się w egzegezie i teologii Starego Testamentu; jannaw@ amu.edu.pl; ORCID: 0000-0002-2498-5081. 
nać pewnego podsumowania stanu biblistyki w środowisku naukowym Poznania w ramach działania Wszechnicy Piastowskiej właśnie na tle zapisów Konstytucji o Objawieniu Bożym soboru. Z Konstytucji tej wynika jednoznacznie, że II sobór watykański za najważniejsze zadanie rozwoju biblistyki uznał przepojenie całości nauczania i życia religijnego Kościoła treścią słowa Bożego oraz zapewnienie wiernym szerokiego dostępu do Pisma św. Chociaż początków aktywności naukowej wielu profesorów należy szukać daleko poza strukturami Wydziału Teologicznego, obecnie może się to dokonywać właśnie w ramach pracy uniwersyteckiej.

\section{Inicjatywy duszpasterskie archidiecezji poznańskiej promujące Pismo św. pośród wiernych}

Z wielu inicjatyw należy wyróżnić te zwłaszcza, których Poznań stał się zaczątkiem w skali krajowej. Kilka bowiem sztandarowych pomysłów na arenie ogólnopolskiej w Poznaniu właśnie rozpoczynało swą karierę. Wiele z późniejszych inicjatyw znalazło swe poparcie w postawie obecnego ordynariusza, ks. abp. Stanisława Gądeckiego, wytrawnego biblisty i gorącego zwolennika niesienia światła słowa Bożego pod strzechy. Powszechnie znana i doceniana jest integrująca rola metropolity poznańskiego zwłaszcza na polu uwrażliwienia na Pismo św. kleru poznańskiego przez różne inicjatywy duszpasterskie: konferencje, dni skupienia, kształcenie permanentne księży. Biblia z oczywistych względów zajmuje w tym kontekście poczesne miejsce.

\section{Dzieło biblijne im. Jana Pawła II ${ }^{2}$}

Od tej zdecydowanie najważniejszej z ogólnopolskich inicjatyw biblijnych należy rozpocząć z racji jej rangi w podnoszeniu kultury biblijnej wierzących w naszym kraju, tym bardziej że w archidiecezji poznańskiej święci ono szczególny triumf, rozwijając się niezwykle dynamicznie za sprawą aktywności organizacyjnej ks. dr. Tomasza Siudy, diecezjalnego moderatora Dzieła. Powstało ono jako jedno z najwcześniej założonych w kraju, bo oficjalnie już 2 grudnia 2006 roku. Dzieło już teraz posiada bezsprzecznie największe zasługi w propagowaniu idei poznawania słowa Bożego na terenie diecezji. Spośród podstawowych

\footnotetext{
${ }^{2}$ Ogólne i szczegółowe wiadomości w tym zakresie dostępne są na http://biblista.pl/. W roku 2006, na I niedzielę adwentu metropolita poznański wystosował specjalny list do diecezjan, zalecając wprowadzenie i ugruntowanie dzieła biblijnego w diecezji. Szczegóły, por. M. Szczepaniak, Abp Gądecki promuje Dzieło Biblijne, 1 grudnia 2006, [online] http://info.wiara.pl/doc/162912. Abp-Gadecki-promuje-Dzielo-Biblijne [4.06.2019].
} 
inicjatyw Dzieła należy wymienić kilka szczególnie interesujących. W Poznaniu organizowane są roczne cykle wykładów obejmujących studium biblijno-patrystyczne z elementami archeologii biblijnej (od roku 2011), a także kursy formacji biblijnej, już obecnie trzyletnie z racji ogromnego zainteresowania słuchaczy. Na poziomie I jest to podstawowy kurs formacji biblijnej, działający od roku 2007. Na poziomie II funkcjonuje kurs pogłębiony, na roku III zaś - studium formacji biblijnej ${ }^{3}$. W ramach Dzieła organizowane są również: szkoła Słowa Bożego dla początkujących ${ }^{4}$, przygotowania do Lectio divina, coroczne konkursy biblijne w różnej formie, rekolekcje biblijne ogólne i specjalistyczne, spotkania z Biblią, wystawy i warsztaty biblijne, celebracje słowa Bożego najróżniejszego typu oraz doroczne Tygodnie Biblijne w parafiach archidiecezji. Odbywają się one nie tylko w samym Poznaniu, lecz także - i to często - w terenie ${ }^{5}$. W tak rozwinięte formy aktywności zaangażowani są liczni wykładowcy Wydziału Teologicznego, naukowcy, duszpasterze oraz świeccy katecheci, przygotowywani w ramach Dzieła.

\section{Ekumeniczne Święto Biblii}

Znakomitą inicjatywą naszego ośrodka teologicznego jest odbywające się od 2001 roku październikowe Ekumeniczne Święto Biblii z bogatym programem skupionym wokół recepcji słowa Bożego w różnych sytuacjach życia współczesnego. Organizatorem jest Poznańska Grupa Ekumeniczna, zrzeszająca Kościoły Chrześcijańskie Miasta Poznania. Obok debat teologiczno-biblijnych, koncertów, spektakli teatralnych i warsztatów plastycznych odbywają się modlitewne spotkania ekumeniczne. Punktem kulminacyjnym Święta jest Ekumeniczne Nabożeństwo Słowa pod przewodnictwem abp. metropolity oraz któregoś z zaproszonych gości z kościołów i wspólnot chrześcijańskich. Również na tym polu należy podkreślić aktywność moderatora diecezjalnego dzieła biblijnego, czyli ks. dr. Tomasza Siudy.

\section{Verba Sacra}

Niezwykle cenna i popularna okazała się zrodzona z okazji jubileuszu 2000-lecia chrześcijaństwa inicjatywa Verba Sacra. Jest to projekt interdyscyplinarny

\footnotetext{
${ }^{3}$ Szczegóły, por. http://biblista.pl/images/Diecezje/Poznanska/Pliki/KURSY-FORMACJI-BIBLIJNEJ-2018.pdf [3.06.2019].

${ }^{4}$ Bogaty plan spotkań i konferencji, por. http://biblista.pl/images/Diecezje/Poznanska/Pliki/ PLAN2017-18.pdf [3.06.2019].

${ }_{5}$ Szczegółowe inicjatywy podawane są w drukowanym rokrocznie Informatorze Dzieła Biblijnego. Niekiedy inicjatywom tym towarzyszy tzw. bibliobus, w którym znajdują się zazwyczaj: wystawa o Biblii, małe kino, biblijne gry komputerowe $\mathrm{i}$ inne.
} 
artystyczno-naukowo-religijny, poświęcony tradycji słowa w kulturze duchowej ze szczególnym uwzględnieniem dziedzictwa europejskiego. Pomysłodawcą projektu jest reżyser Przemysław Basiński przy wydatnej współpracy Wydziału Teologicznego Uniwersytetu im. Adama Mickiewicza. Jak pisze w broszurze informującej reżyser:

realizację rozpoczęto w styczniu 2000 roku w formie cyklu dwunastu prezentacji tekstów biblijnych. Od początku spotkał się on z bardzo szerokim oddźwiękiem społecznym i został uznany za jedno z najbardziej spektakularnych wydarzeń Wielkiego Jubileuszu. Na temat Verba Sacra napisano około 3000 publikacji artykułów, recenzji, informacji. Liczbę uczestników oceniono na ponad 300000 osób. Od swego zarania aż do obecnego roku odbyło się już 201 prezentacji cyklu. W części prezentującej poszczególne księgi biblijne, recytowane przez najwybitniejszych artystów scen polskich, publiczność ma okazję wysłuchania komentarzy biblijnych przygotowywanych przez wszystkich w zasadzie biblistów polskich z całego kraju. Od stycznia roku 2000 odbywała się co miesiąc prezentacja jednego utworu w formie uroczystej recytacji przez aktora. Na miejsce prapremiery wybrano najstarszą świątynię polską — Bazylikę Archikatedralną pw. św. Ap. Piotra i Pawła w Poznaniu. Kolejne edycje odbyły się w katedrach i kościołach: Bielska-Białej, Częstochowy, Gdańska, Gniezna, Katowic, Krakowa, Legnicy, Lublina, Obornik, Pelplina, Radomia, Siemiatycz, Tarnowa, Trzebnicy, Torunia, Warszawy, Wejherowa, Wrocławia, Zakopanego. Obecnie cykl jest kontynuowany, a także na Litwie w cyklu „modlitwy katedr polskich i europejskich”.

Wszyscy wykładowcy i profesorowie Wydziału Teologicznego w Poznaniu mieli okazję zaprezentować przygotowane przez siebie wprowadzenia w lekturę poszczególnych ksiąg biblijnych w ramach tego projektu. Od roku 2019 szczególnie udziela się natomiast ks. prof. Janusz Nawrot, przygotowując wybór tekstów oraz wszystkie wprowadzenia do ksiąg.

\section{Maraton biblijny}

To kolejny, znakomity pomysł promujący słowo Boże wśród mieszkańców zwłaszcza Poznania. Jest to wielogodzinne czytanie Biblii organizowane corocznie przez Duszpasterstwo Młodzieży Archidiecezji Poznańskiej oraz biuro Verba Sacra. Organizatorzy stawiają sobie za cel ponowną ewangelizację wiernych, którzy w życiu codziennym na ogół nie czytają Biblii. Pierwszy Maraton Biblijny odbył się w roku 2005 w kościele Wszystkich Świętych w Poznaniu i trwał

${ }^{6}$ Por. P. Basiński, O Verba Sacra, [online] http://www.verbasacra.pl/index.php?option=com content\&view $=$ article $\& i d=10 \&$ Itemid $=2$ [3.06.2019]. 
dokładnie 119 godzin 2 minuty i 42 sekundy. Pismo Święte Starego i Nowego Testamentu czytało wówczas 876 osób bez przerwy przez pięć dni i nocy. W sesji wzięli udział urzędnicy (m.in. prezydent miasta Poznania, marszałek województwa wielkopolskiego) i przedstawiciele innych kościołów (m.in. Zielonoświątkowego oraz Prawosławnego). Drugi Maraton w roku 2006 trwał dziesięć dni. Ze względu na bardzo duże zainteresowanie poznaniaków cała księga Biblii została podzielona na 1500 fragmentów. Tym razem zrezygnowano z czytania non-stop, tak więc lektura trwała od porannej mszy do późnych godzin wieczornych. Najmłodszy uczestnik maratonu miał 6,5 roku, najstarszy zaś 87 lat. W Maratonie wzięli udział m.in. trener i piłkarze Lecha Poznań oraz zespół Arka Noego. Trzeci Maraton w marcu 2007 zorganizowano w trzynastu kościołach całego Poznania, czytanie zaś trwało trzynaście dni. Pismo Święte ponownie podzielono na 1500 fragmentów. Czwarta edycja Maratonu została zorganizowana w lutym i marcu 2008 w osiemnastu kościołach Poznania oraz dwóch poza jego granicami, gdzie przez dwadzieścia dni ponownie czytano 1500 fragmentów. Obecnie inicjatywa ta przeszła w tzw. Narodowy Dzień Czytania Pisma Świętego i w roku 2019 odbył się już trzeci, w niedzielę 5 maja pod hasłem „Niech zstąpi Duch Twój i odnowi oblicze ziemi, tej ziemi!"’.

\section{Dzień Judaizmu}

Ważne miejsce zajmuje także promowany szeroko w kraju od 1997 roku coroczny Dzień Judaizmu w szerokim kontekście biblijnym. W naszej diecezji rozłożony jest on z reguły na kilka dni z bogatą i różnorodną tematyką historyczną, kulturalną i biblijną. Rangę temu świętu kultury żydowskiej nadaje patronat honorowy, który - jak co roku - obejmuje arcybiskup metropolita poznański, wielki kanclerz Wydziału Teologicznego UAM wraz z marszałkiem województwa wielkopolskiego, prezydentem miasta Poznania oraz dyrektorem Biblioteki Kórnickiej PAN. W niektórych latach komentarze do poszczególnych przedstawień przygotowywał ks. prof. Jan Kanty Pytel, związany zwłaszcza z promocją twórczości Romana Brandstaettera ${ }^{8}$. Obok niego aktywni byli także dr hab. Teresa Stanek, ks. prof. Paweł Bortkiewicz oraz prof. Tomasz Węcławski, ówczesny pracownik naszego Wydziału9. Od kilku lat w Poznaniu dzień ów wydłużony zo-

7 Por. http://biblista.pl/diecezja-poznanska/wydarzenia-poznanska/6770-trzecie-narodowe-czytanie-pisma-swietego.html [3.06.2019].

811 stycznia 2004 roku Ksiądz Profesor wygłosił komentarz do Psalmów w tłumaczeniu Brandstaettera przed monodramem Olgierda Łukaszewicza w ramach VI Dnia Judaizmu.

914 stycznia 2004 roku profesor Stanek, adiunkt na Wydziale Teologicznym, przybliżyła kulinarny temat „Wokół żydowskiego stołu”. Dzień później ks. Bortkiewicz poprowadził dyskusję panelową podczas sympozjum „Staniecie się błogosławieństwem”. Ks. Węcławski wygłosił referat „Wiara spotyka wiarę” podczas sympozjum „Czerpiąc z korzenia dobrej oliwki”, o reperkusjach 
stał na cały tydzień poprzedzający bezpośrednio Tydzień Powszechnej Modlitwy o Jedność Chrześcijan. Tak więc ,jeden” dzień wydłuża się na imprezy przypadające najczęściej między 10 a 19 stycznia. Każdorazowo pojawia się inne hasło lub zawołanie, wyciągnięte z któregoś tekstu starotestamentowego. XXII Dzień Judaizmu odbywał się pod hasłem „Nie przyszedłem, aby zatracać. Poznaj kulturę żydowską". Złożyły się na niego koncerty, spektakle, seanse filmowe, spotkania, wystawy, nabożeństwo i dyskusje ${ }^{10}$.

\section{Kręgi biblijne w parafiach diecezji}

W archidiecezji poznańskiej funkcjonują także liczne koła biblijne w parafiach, prowadzone przez wykładowców Wydziału Teologicznego UAM, niekiedy także — chociaż wcale nierzadko — przez księży parafialnych. W działalność tę jest zaangażowanych kilkadziesiąt parafii i ośrodków zakonnych ${ }^{11}$. Godne odnotowania są ponadto niedziele i tygodnie biblijne w parafiach oraz biblijne spotkania okolicznościowe.

\section{Przekłady Pisma Świętego}

\section{Biblia poznańska}

Celem spopularyzowania tekstu biblijnego oraz zadośćuczynienia pragnieniu soboru w ośrodku poznańskim dokonano jednej z najważniejszych w Polsce inicjatyw na tym polu, jaką było pojawienie się tzw. Biblii poznańskiej, drugiego po Biblii Tysiąclecia przedsięwzięcia o tym charakterze ${ }^{12}$. Sama idea podjęcia no-

dokumentu Nostra aetate II soboru watykańskiego, w roku 2006 w ramach IX Dnia Judaizmu. 10 stycznia 2008 roku, podczas XI Dnia Judaizmu odbył się wernisaż wystawy fotograficznej „Dialog — dopokąd czuję, rozumiem i widzę...” w ramach projektu „W stronę wyobraźni dialogu” realizowany przez Wydział Teologiczny UAM, Stowarzyszenie COEXIST i Akademię Sztuk Pięknych w Poznaniu. Szczegóły programu każdego z obchodzonych dni czytelnik znajdzie na stronie internetowej stowarzyszenia COEXIST: http://coexist.pl/dzien-judaizmu/.

${ }^{10}$ Szczegóły, por. M. Zaradniak, Dzień Judaizmu w Poznaniu 2019. Nie przyszedtem, aby zatracać. Poznaj kulturę żydowska, 11 stycznia 2019 [online] https://gloswielkopolski.pl/dzien-judaizmu-w-poznaniu-2019-nie-przyszedlem-aby-zatracac-poznaj-kulture-zydowska/ar/13800031 [3.06.2019].

${ }_{11}$ Autor niniejszego artykułu prowadzi ich w sumie $11 \mathrm{w}$ ośrodkach i parafiach poznańskich oraz w terenie, niewymienionych w pozostałych statystykach.

${ }^{12} \mathrm{O}$ wadze całego przedsięwzięcia świadczą liczne recenzje opublikowane w całym kraju na łamach najróżniejszych czasopism; por. H.J. Kaczmarski, Polskie przekłady Pisma Św. IV. Biblia Poznańska, „Za i Przeciw” 41 (1974), s. 8; tenże, Biblia Poznańska i inne przekłady Pisma Świętego, „Za i Przeciw” 17 (1976), s. 8; tenże, Trzytomowa Biblia wydana w Poznaniu, w: Przekłady 
wego thumaczenia Pisma Świętego wyszła nieco wcześniej niż prace soborowe, bo już w 1960 roku, od ks. Aleksego Klawka, kapłana archidiecezji poznańskiej, profesora Uniwersytetu Jagiellońskiego w Krakowie, chociaż nie została w pełni wcielona $\mathrm{w}$ życie ${ }^{13}$. Projekt postanowiono jednak kontynuować w Poznaniu, a jego efektem jest Pismo Święte Starego i Nowego Testamentu w przekładzie z języków oryginalnych ze wstępami i komentarzami. Dzieło opracował zespół pod redakcją ks. prof. Michała Petera (Stary Testament) oraz ks. prof. Mariana Wolniewicza (Nowy Testament), początkowo w trzech tomach z obszernymi komentarzami i wstępami do poszczególnych ksiąg ${ }^{14}$. Obok Biblii Tysiąclecia

oba te przekłady [...] są wyróżniającym świadectwem zespołowej pracy polskich biblistów, dobrze przygotowanych do swoich zadań. Stawiają one Polskę w rzędzie krajów wspaniale rozwijającego się ruchu biblijnego, gdzie wierni otrzymali „szeroki dostęp do Pisma Świętego" (DV 22) za pośrednictwem większej liczby przekładów z języków oryginalnych ${ }^{15}$.

W nocie od wydawnictwa znalazła się ważna wzmianka, że to właśnie Poznań, jako stolica najstarszej polskiej diecezji, powinien „upamiętnić się przez wydanie tak pomnikowego dzieła", składając w ten sposób także hołd archidiecezji, oddany wierze i Kościołowi w Polsce na jego tysiąclecie. Godne odnotowania jest też to, że mimo rozwiniętego ruchu biblijnego w Polsce przez kilka stuleci — od czasów ks. Jakuba Wujka - nie sposób było poszczycić się nowym tłumaczeniem ksiąg świętych ${ }^{16}$.

Spośród charakterystycznych cech przekładu starotestamentowego należy wyróżnić przede wszystkim daleko idącą wierność oryginałowi, mającą niekie-

Pisma Świętego na język polski po II wojnie światowej, „Novum” 4-5 (1977), s. 70-72; A. Radwanowa, W poznańskim środowisku teologicznym. Biblistyka — nauka żywa i aktualna, ,Słowo Powszechne", 178 (1974), s. 6-7; W. Smereka, Biblia Poznańska (O nowym polskim przektadzie Pisma Świętego), „Tygodnik Powszechny” 20 (1974), s. 7; tenże, Biblia Poznańska. Nowy przekład Pisma Św, „Gość Niedzielny” 23 (1974), s. 178-180; tenże, Nowy przekład z pożytecznym komentarzem, „Przegląd Katolicki” 20 (1975), s. 11; Z. Szuba, Zakończenie edycji Biblii Poznańskiej, „Słowo Powszechne” 71 (1976), s. 7; [J. Turnau] Turian, Mamy nową Biblię, „Więź” 9 (1976), s. 26-31.

${ }^{13}$ Por. Pismo Święte Starego i Nowego Testamentu w przekładzie z języków oryginalnych ze wstępami i komentarzami (Biblia Poznańska), t. 1-3, oprac. zespół pod red. M. Petera (Stary Testament) i M. Wolniewicza (Nowy Testament), słowo wstępne: A. Baraniak, C. Jakubiec, Wprowadzenie w lekturę Pisma Świętego, Poznań 1973-1975, t. 1, s. VII.

14 Tłumaczenie tekstów hebrajskich dokonane zostało na podstawie tekstu masoreckiego $\mathrm{Bi}$ blia Hebraica, ed. R. Kittel, P. Kahle, A. Alt, O. Eissfeld, Stuttgart 1951, greckich zaś na podstawie Septuaginty A. Rahlfsa, Stuttgart 1943. Jeśli chodzi o Nowy Testament, to tekstem oryginału był The Greek New Testament, ed. K. Aland, M. Black, B.M. Metzger, A. Wikgren, Stuttgart $1968^{2}$.

${ }_{15}$ Słowo wstępne arcybiskupa poznańskiego A. Baraniaka, por. Pismo Święte..., t. 1, s. V.

16 Por. tamże, s. VI. 
dy pierwszeństwo przed pięknem języka polskiego. Stało się tak, by upewnić czytelnika, że ma on przed sobą autentyczny tekst biblijny, a nie jego parafrazę. Pozwala to jednak traktować tekst jako w pełni źródłowy. Godna uwagi jest także pośrednia droga, jaką wybrali thumacze między nadmiarem a niedomiarem semityzmów jako specyfiki języka oryginalnego. Czytelnik poznaje w ten sposób smak starożytnych sformułowań, co jednak nie razi niezrozumiałością z racji względnej ich obecności w przekładzie. Z innych cech wymienić można jeszcze celne dostosowywanie brzmień niektórych zwrotów i konstrukcji językowych do prawideł języka polskiego, archaizacja niektórych miejsc i sposobów wypowiedzi, modernizacja utartych, zwłaszcza w Biblii Tysiąclecia zwrotów i nazw technicznych, eufemizacja niektórych co bardziej drastycznych tekstów z podaniem ich dosłownego thumaczenia w przypisach, pisownia imion własnych według oryginału masoreckiego. Podkreślenia wymaga także trudna praca dostosowywania składni, fleksji języka oryginalnego do współczesnych kryteriów języka polskiego oraz zapis układu rytmicznej poetyki i prozodii hebrajskiej, widoczny w tekście w strukturze wierszowanej, w odróżnieniu od ciaggłego tekstu, relacjonującego faktograficznie poszczególne wydarzenia ${ }^{17}$. Z kolei zespół tłumaczy Nowego Testamentu zetknął się z zadaniem poniekąd nawet trudniejszym, ponieważ przekładu Starego Testamentu dokonano po II soborze watykańskim właściwie tylko raz, w Biblii Tysiąclecia, podczas gdy przekładów Nowego ukazało się już osiem, w tym siedem po II wojnie światowej ${ }^{18}$. Pierwsze wydanie Biblii Poznańskiej zawierało trzy tomy: dwa przypadały na Stary Testament $\mathrm{i}$ jeden na Nowy, z następującym podziałem: tom 1 zawiera księgi od Księgi Rodzaju do 2 Księgi Machabejskiej w objętości 944 stronic. Tom 2 zawiera księgi od Księgi Tobita do Księgi Malachiasza, o objętości 1332 stronic. Tom 3 zawiera wszystkie pisma Nowego Testamentu o objętości 679 stronic. Chociaż, podobnie do Biblii Tysiąclecia, także w przekładzie Biblii poznańskiej pojawiło się ogólnopolskie grono thumaczy, gros przekładów poszczególnych ksiąg dokonali miejscowi bibliści. W Starym Testamencie wyróżnia się praca ks. prof. Petera, który przethumaczył cały Pięcioksiąg, ks. prof. Wolniewicz zaś przełożył w Nowym Testamencie cztery Ewangelie, ks. dr E. Szymanek TChr przetłumaczył List do Rzymian i do Galatów, ks. prof. Pytel zaś - Listy do Efezjan, do Filipian, do Kolosan oraz do Filemona.

Biblia poznańska posiada bardzo dobry, rozszerzony w porównaniu z Biblią Tysiąclecia, komentarz historyczno-teologiczny, a także obszerne wstępy do poszczególnych ksiąg ${ }^{19}$. Wydanie IV od 1990 roku zostało uaktualnione i pojawiło

\footnotetext{
17 Por. tamże, s. VII-IX.

18 Tłumacze wzięli tu pod uwagę przekłady ks. E. Dąbrowskiego, Brytyjskiego i Zagranicznego Towarzystwa Biblijnego, ks. ks. W. Szczepańskiego, F. Gryglewicza, S. Kowalskiego oraz świecki - W. Witwickiego.

19 Na szczególną uwagę zasługuje wprowadzenie w lekturę Pisma Świętego, zajmujące pokaźną liczbę dziesięciu stronic, zawierające liczne odwołania do soborowej konstytucji Dei Verbum.
} 
się już w czterech tomach. Chyba mało znany pozostaje fakt, że w ankiecie biblistów polskich z 1999 roku to nie Biblia Tysiąclecia została uznana za najlepszy przekład polski, lecz Biblia poznańska. W latach następnych Biblia poznańska była wielokrotnie wznawiana $\mathrm{z}$ racji swej niebywałej popularności i konieczności rozpowszechniania. Poszczególne lata to: 1973-1975, 1982, 1998-1999 oraz 2004. Z kolei druk od 1990 roku został uaktualniony i pojawił się już w czterech tomach, ponieważ tom II został rozbity na księgi prorockie i mądrościowe. W edycjach z lat 1998 i 2004 Biblia poznańska jest dostępna w kilku formatach. Wydanie pełne, czterotomowe, ma dołączoną całość przypisów i obszerne wprowadzenia do poszczególnych ksiąg ${ }^{20}$.

\section{Pojedyncze księgi biblijne w tlumaczeniach naukowców poznańskich w okresie posoborowym}

Także na tym polu można zaobserwować znaczną aktywność twórczą poznańskiego środowiska uniwersyteckiego. Już w 1965 roku ks. prof. Peter dokonał thumaczenia dwóch ksiąg Starego Testamentu - Księgi Malachiasza i Księgi Aggeusza - na potrzeby Biblii Tysiąclecia, opatrując je stosownym komentarzem. W przekładzie nowotestamentowym wspomnieć natomiast trzeba pracę ks. prof. Wolniewicza, który w tym samym roku przetłumaczył Dzieje Apostolskie, także z własnym komentarzem. Można chyba powiedzieć, że mimo dość znacznej negatywnej krytyki, jaką wzbudziła pierwsza edycja Biblii Tysiąclecia, jakość prób translatorskich obu profesorów pozostaje poza podejrzeniami. Co do umiejętności translatorskich ks. prof. Peterowi, mimo że był młodym, czterdziestotrzyletnim biblistą, nie można stawiać zarzutów. Ukończone studia specjalistyczne na Uniwersytecie Jagiellońskim (1950-1953), znakomita znajomość języka hebrajskiego, wyprawa naukowa Instytutu Biblijnego w Rzymie do Ziemi Świętej, wreszcie zdobycie tytułu naukowego profesora każe wnioskować o dobrej jakości przekładów ksiąg na-

\footnotetext{
Z kolei Nowy Testament został poprzedzony zarówno pięciostronicowym wprowadzeniem ogólnym do Ewangelii, jak i szczegółowym, do każdego z pism, a także pokaźnym komentarzem filologiczno-egzegetycznym oraz teologicznym do wszystkich ksiąg, co niewątpliwie podnosi jego walor poznawczy w wydaniu poznańskim. Dodatkowo należy zauważyć, że we wszystkich częściach komentarz ten nie nuży ilością szczegółowego i trudnego do zrozumienia przez czytelnika materiału naukowego, choć próbuje odpowiedzieć na wnikliwe nieraz zagadnienia pojawiające się przy okazji rozpatrywanego tekstu.

${ }^{20}$ Do niektórych wydań dodawany jest Nowy Testament na CD-ROM-ie. Pojawiło się także wydanie jednotomowe, również w edycjach pamiątkowych i bibliofilskich, wreszcie wielkie jednotomowe wydanie przenośne z przypisami skróconymi oraz małe, bez przypisów. Szczegółowsze omówienie znaczenia Biblii poznańskiej, por. także J.K. Pytel, Twarz Biblii Poznańskiej w reflektorze historii, w: Credidimus caritati. Księga pamiątkowa dedykowana Księżom Profesorom Ryszardowi Figlowi i Tadeuszowi Haneltowi w 70. rocznice urodzin, red. M. Olczyk, P. Podeszwa, Gniezno 2010, s. 409-413.
} 
tchnionych ${ }^{21}$. Z drugiej strony o jego fachowości i kompetencjach wyraźnie świadczą przygotowanie późniejszej Biblii poznańskiej i autorytet, jakim powszechnie cieszył się w środowisku egzegetycznym całego kraju. Kompetencji translatorskich ks. prof. Wolniewicza nie sposób podawać w jakąkolwiek wątpliwość dzięki odbytym studiom specjalistycznym na Katolickim Uniwersytecie Lubelskim, tamtejszym lektoratom, zwłaszcza greki oraz dwumiesięcznej podróży naukowej do Ziemi Świętej Papieskiego Instytutu Biblijnego w Rzymie. W pełni potwierdziło to także kierowanie przezeń zespołem tłumaczy Nowego Testamentu Biblii Poznańskiej ${ }^{22}$.

Spośród innych uczonych środowiska poznańskiego na wyróżnienie zasługuje także praca ks. prof. Tomasza Węcławskiego, który w 1987 roku — będąc teologiem, nie biblistą — przełożył cztery Ewangelie na język dziecięcy, tworząc jedną historię życia Jezusa Chrystusa. Sam autor zaznaczył, „że nie można tego tekstu stawiać na równi z dokładnymi tłumaczeniami. Ważną rolę w tej książce odgrywa język. Jest potoczny i zrozumiały, ale nie infantylny. Nie ma tu hebraizmów, a trudne pojęcia przedstawiane są opisowo"23. Z kolei w 1999 roku autor podał własne tłumaczenie tekstu Ewangelii św. Marka ${ }^{24}$.

W roku jubileuszowym 2000 ks. prof. Bogdan Poniży wydał swe dzieło Księga Madrości. Od egzegezy do teologii ${ }^{25}$. Nie jest to wprawdzie jeszcze komentarz sensu stricto do rzeczonej w temacie księgi, lecz można to dzieło uznać za znakomity wstęp do przygotowanego później tomu serii „Nowego Komentarza Biblijnego". Warto tu może wspomnieć, że ksiądz profesor jest autorem kilkudziesięciu artykułów naukowych dotyczących Księgi Mądrości i jednym z najwytrawniejszych jej znawców w biblistyce polskiej oraz światowej. Komentarz ten ukazał się w ramach Nowego Komentarza Biblijnego Starego Testamentu, nakładem Edycji św. Pawła w Częstochowie w roku 2012.

W 2002 roku ukazała się inna bardzo ważna praca, tym razem w dziedzinie badań egzegetycznych nad 1 i 2 Księgą Machabejską, której autorem jest obecny metropolita poznański, abp dr Stanisław Gądecki. Jest to Grecko-łacińsko-polska synopsa do Pierwszej i Drugiej Ksiegi Machabejskiej, zawierająca tekst obu ksiąg, odnośne cytaty dzieł Józefa Flawiusza i innych historyków pogań-

${ }^{21}$ Szczegółowe opracowanie życia i pracy księdza profesora, por. M. Banaszak, Profesor Michat Peter (1922-1982), w: F. Lenort, Requinte in libro Domini: Michaeli Peter piae memoriae dedicata, t. 6, Poznań 2005, s. 247-255. Ogromny dorobek pisarski autora, por. J. Kierstan, M. Przepióra, Bibliografia prac drukowanych Księdza Profesora Michała Petera, w: F. Lenort, Requirite in libro Domini: Michaeli Peter piae memoriae dedicata, t. 6, Poznań 2005, s. 287-300.

${ }^{22}$ Całość swego życia ks. prof. Wolniewicz przedstawił w niezwykle barwnej Autobiografii, wydanej z okazji 80-lecia jego życia w: Scriptura Sacra Posnaniensis. Opuscula Mariano Wolniewicz octogenario dedicata, red. F. Lenort, t. 3, Poznań 2002, s. 253, w której skromnie pominął swój ogromny wkład w pracę dla Biblii Tysiąclecia Poznańskiej.

23 Por. T. Węcławski, Ewangelia dla dzieci, Kraków $2006^{2}$.

${ }^{24}$ Por. tenże, Dobra nowina wedlug świętego Marka, Poznań 1999.

${ }^{25}$ Por. B. Poniży, Księga Mądrości. Od egzegezy do teologii, Poznań 2000, ss. 251. 
skich wraz z wstępem ${ }^{26}$. Samo tłumaczenie obu ksiąg ukazało się w „Studiach Gnieźnieńskich" w roku $1999^{27}$.

Żeńską stronę poznańskich naukowców uniwersyteckich w dziedzinie egzegezy reprezentuje z kolei dr hab. Teresa Stanek, świetna znawczyni hebrajszczyzny biblijnej, która w 2003 roku dokonała własnego przekładu Księgi Rut ${ }^{28}$. Rok później pojawiło się jej tłumaczenie Księgi Jonasza ${ }^{29}$, w 2005 roku zaś przełożyła na język rodzimy tekst Księgi Habakuka ${ }^{30}$.

Rok 2007 w naszym środowisku naukowym zapisał się wydaniem przekładu Księgi Apokalipsy autorstwa ks. prof. Jana Kantego Pytla ${ }^{31}$. Wydanie to zawiera nie tylko nowy przekład księgi apostoła Jana z języka greckiego, lecz także wprowadzenie do lektury wraz z obszernym komentarzem zatytułowanym Zbawcze przestanie Apokalipsy dla Kościoła. Publikacja oprócz samej księgi, obejmuje omówienie gatunków literackich i symboli w Apokalipsie oraz wyjaśnienie zasad interpretacji dzieła Jana. Egzegetycznym opisom wizji św. Jana towarzyszą tyleż nowatorskie środki ekspresji, co barwne ilustracje autorstwa krakowskiego rysownika, Grzegorza Bednarskiego.

Godne szczególnego podkreślenia — a zarazem najnowsze — są thumaczenia Biblii o. prof. Adama Ryszarda Sikory OFM na język kaszubski. Skala całości przedsięwzięcia i wynikająca z niego waga pracy ojca profesora dla wspólnoty polskich Kaszubów i kultywowanego przez nich rodzimego języka są nie do przecenienia. W 2001 roku ukazał się przekład Ewangelii św. Marka ${ }^{32}$ w 2007 roku zaś - przekład Ewangelii św. Jana ${ }^{33}$. Dwa lata później ojciec profesor dokonał przekładu Ewangelii św. Mateusza ${ }^{34}$, a w 2010 roku pojawił się przekład Ewangelii św. Łukasza ${ }^{35}$. W tym samym roku ukazał się także całościowy prze-

26 Por. Grecko-łacińsko-polska synopsa do Pierwszej i Drugiej Księgi Machabejskiej, tłum. i oprac. S. Gądecki, Prymasowska Seria Biblijna 19, Warszawa 2002, ss. 450; tenże: Uwagi do nowego przekładu 1 Mch, „Studia Gnesnensia” 13 (1999), s. 5-6; tenże: Trudności związane z ttumaczeniem Pisma Świętego na przykładzie 2. Księgi Machabejskiej, „Ziemia Wągrowiecka” 1 (1998), s. 19-28.

27 Por. tenże, I Księga Machabejska, „Studia Gnesnensia” 13 (1999), s. 7-51; tenże: II Księga Machabejska, „Studia Gnesnensia” 13 (1999), s. 53-84.

28 Por. T. Stanek, Księga Rut: Propozycja nowego przekładu na podstaw masoreckiego, „Poznańskie Studia Teologiczne" 15 (2003), s. 9-29.

29 Por. taż, Księga Jonasza. Przekład filologiczny na podstawie tekstu masoreckiego, „Biblia i Ekumenizm" 1/2004 s. 31-45.

30 Por. taż, Księga Habakuka. Przesłanie i przekład filologiczny na podstawie tekstu masoreckiego, w: Requirite in Libro Domini. Opuscula Michaeli Peter piae memoriae dedicata, red. F. Lenort, (Opuscula Dedicata 6), Poznań 2005, s. 97-110.

31 Por. Apokalipsa św. Jana Apostoła, tłum. i komentarz J.K. Pytel, Poznań 2007.

32 Por. A.R. Sikora, Ewanielejó wedle swiategó Marka, Gduńsk 2001.

33 Por. tenże, Ewanielejó wedle swiategó Jana, Gduńsk 2007.

34 Por. tenże, Ewanielejó wedle swiategó Mateusza, Gduńsk 2009.

35 Por. tenże, Ewanielejó wedle swiategó Łukasza, Kartuzy 2010. 
kład tekstów ewangelijnych, zebrany w jednym dziele ${ }^{36}$. Warte wspomnienia jest również przełożenie na kaszubski serii trzydziestu psalmów w ramach odbywających się do tej pory cyklicznych spotkań Verba Sacra w Wejherowie, rodzinnym mieście ojca profesora ${ }^{37}$. Tłumacz oczywiście nie poprzestał na Nowym Testamencie, do którego wydał jakże potrzebną dla różnorakich zestawień synopsę ewangelii ${ }^{38}$. Obecnie wielkim jego dziełem jest Pięcioksiąg Mojżeszowy, który niemal w całości został już przełożony na język kaszubski ${ }^{39}$.

$\mathrm{Na}$ koniec autor niniejszego artykułu przetłumaczył i komentarzem filologiczno-historycznym oraz teologicznym opatrzył Pierwszą Księgę Machabejską w ramach ogólnopolskiej serii Nowego Komentarza Biblijnego. W roku 2016 ukazała się pierwsza część komentarza ${ }^{40}$, druga zaś jest obecnie w redakcji, czekając na wydanie. Niejako wstępem do tej książki stała się wydana w 2012 roku w Poznaniu prezentacja teologii 1 Mch 1,1-2,25 $5^{41}$ i kilkanaście artykułów naukowych, związanych z omawianą problematyką księgi.

\footnotetext{
${ }^{36}$ Por. tenże, Ewanielie na kaszëbsczi tlomaczoné, Gduńsk 2010.

${ }^{37}$ Por. tenże, Komentarz teologiczny i przekład. Księga Psalmów, w: Verba Sacra, Biblia Kaszubska. Księga Psalmów, Wejherowo 2011, s. 3-6, 7-21; tenże, Komentarz teologiczny i przektad. Księga Psalmów, w: Verba Sacra, Biblia Kaszubska, Księga Psalmów, cz. II: Psalmy w Nowym Testamencie, Wejherowo 2012, s. 3-6, 8-33. Pośród prac na temat przekładów wymienić należy: tenże, Ewangelia wedtug św. Jana na kaszubski tlumaczona. Przekłady z języków niebiblijnych a przekład z języka greckiego, Poznań 2006; tenże, Teksty biblijne w najstarszych zabytkach piśmiennictwa kaszubskiego (XVI-XVIII w.), Poznań 2009 oraz tenże, Biblia Kaszubska. Verba Sacra $w$ Wejherowie 2004-2008, Wejherowo 2008.

${ }_{38}$ Por. tenże, Zestawienié synopticzné szterzech Ewanielii na kaszëbsczi tolmaczonëch, Poznań 2014 oraz tenże, Nowi Testameńt. Ewanielie pò kaszëbskù, Gduńsk 2014².

${ }^{39}$ Por. Knéga Zôczątków [Księga Rodzaju], z hebrajsczégò jâzëka na kasëbsczi przełożit ò. Adam Ryszard Sikora OFM, Gduńsk 2015; Knéga Wińdzeniô: Exodus [Księga Wyjścia], z hebrajsczégò jãzëka na kaszëbsczi przełożit Adam Ryszard Sikora, Gduńsk 2016; Knéga Kapłańskô Leviticus [Księga Kapłańska], z hebrajsczégò jãzëka na kaszëbsczi przełoził ò. Adam Ryszard Sikora OFM, Gduńsk 2017; Knéga Lëczbów [Księga Liczb], z hebrajsczégò jâzëka na kasëbsczi przełożit ò. Adam Ryszard Sikora OFM, Gduńsk 2018. Tłumaczenie Księgi Powtórzonego Prawa jest już w wydawnictwie. Pełen dorobek naukowy o. profesora znaleźć można na: https://teologia. amu.edu.pl.

40 Por. J. Nawrot, Pierwsza Księga Machabejska. Rozdziały 1,1-6,16, Nowy Komentarz Biblijny. Stary Testament XIV/I, Częstochowa 2016, ss. 843.

${ }^{41}$ Por. tenże, Kryzys religijny w Judei za Antiocha IV Epifanesa. Teologia historii $w 1$ Mch 1,1-2,26, (Studia i Materiały 151), Poznań 2012.
} 


\section{Badanie i wykład Biblii w seminariach $w$ celu lepszego przygotowania księży do nauczania ludu}

W tym względzie warto podkreślić zwłaszcza starania ówczesnego arcybiskupa metropolity poznańskiego Antoniego Baraniaka oraz wykładowców Arcybiskupiego Seminarium Duchownego. Ich skutkiem był Dekret Kongregacji Wychowania Katolickiego Posnaniensis urbs z 2 czerwca 1974 roku erygujący w Poznaniu Papieski Wydział Teologiczny. Wydział powstał i przez pierwsze lata działał w seminarium w Poznaniu ze znanych wówczas powodów politycznych i jak wszędzie przez długie lata nie był uznawany przez państwo komunistyczne, podlegając tym samym szykanom ze strony władz co wszystkie inne kościelne ośrodki naukowe w Polsce. Zmiany stały się możliwe - jak wiadomo - dopiero po roku 1991. Ostatecznie Kongregacja Wychowania Katolickiego pismem z 26 czerwca 1998 roku (Prot. N. 124/98) wyraziła formalną zgode na ustanowienie Wydziału Teologicznego w Uniwersytecie im. Adama Mickiewicza oraz zdeklarowała, że działalność istniejącego dotąd Papieskiego Wydziału Teologicznego w Poznaniu, jak też jego prawa, przywileje i honory, którymi cieszą się wydziały teologiczne erygowane przez Stolicę Apostolską, mogą zostać przeniesione na Wydział Teologiczny UAM. 29 czerwca 1998 roku Senat Uniwersytetu im. Adama Mickiewicza w Poznaniu podjął decyzję, na mocy której utworzył Wydział Teologiczny tegoż Uniwersytetu. Obie decyzje wydatnie przyczyniły się do rozwoju teologii jako nauki w naszym regionie, co szczęśliwie trwa do dziś.

W minionym okresie niemal 40-lecia powojennego w przygotowaniu alumnów seminarium do podjęcia myślenia soborowego w dziedzinie biblijnej środowisko poznańskie może pochwalić się zwłaszcza monumentalnym podręcznikiem egzegezy Starego Testamentu, przygotowanym przez ks. prof. Michała Petera. Podręcznik ów stał się jednym z najbardziej bodaj sztandarowych dzieł wykładu egzegezy Starego Testamentu w seminariach polskich. Pierwsza edycja ukazała się już w roku 1959, stosując szeroko znane wówczas zasady interpretacji Pisma św., podane zwłaszcza w encyklice Piusa XII Divino afflante Spiritu z roku 1943. Książka była później jeszcze kilkakrotnie uwspółcześniania na podstawie danych soboru: 1970, 1978 i 2005 . Znane są także polemiki ks. prof. Petera z ówczesnymi tuzami socrealizmu w Polsce, którzy zajmowali się Pismem św., jak Artur Sandauer, a także innymi publicystami, jak Tadeusz Żychiewicz.

Drugą wartościową pozycją naukową, choć pisaną językiem popularyzatorskim, jest seria artykułów pracowników wydziału, zebrana w jednym tytule: Nie wstydze się Ewangelii. Księga Dziejów Apostolskich, pod redakcją ks. prof. Pytla $^{42}$. Ukazała się w przeddzień jubileuszowego roku dwutysiąclecia chrześcijaństwa i założenia Kościoła przez Jezusa Chrystusa. Ów właśnie jubileusz legł

\footnotetext{
${ }^{42}$ Por. Nie wstydzę się Ewangelii. Księga Dziejów Apostolskich, red. J.K. Pytel, Szczecin 1999.
} 
u podstaw pomysłu powstania pracy zbiorowej promującej znajomość księgi opowiadającej początki Kościoła. W pracę włączyło się całe środowisko młodych naukowców, dając nawet mniej wprawionemu czytelnikowi dostępną egzegezę tematyczną w poszczególnych rozdziałach książki. Należy jedynie mocno żałować, że rozpoczęta tym tomem seria „Nie wstydzę się Ewangelii”, której zamierzeniem było opracowanie tematyczne poszczególnych części Nowego Testamentu, nie została dokończona mimo wysiłków niektórych autorów. W książce tej swe artykuły zamieścili: redaktor, ks. prof. Bogdan Poniży, Piotr Ostański i Janusz Nawrot.

\section{Prowadzenie badań naukowych nad Pismem św. pod nadzorem Urzędu Nauczycielskiego Kościoła}

W okresie posoborowym badawcze zainteresowania poznańskiego naukowego ośrodka biblijnego rozwinęły się przede wszystkim w kierunkach wyznaczonych konstytucją Dei Verbum, choć wcześniej były inspirowane encyklikami papieży: Leona XIII Providentissimus Deus oraz Piusa XII Divino afflante Spiritu, a także orzeczeniami Papieskiej Komisji Biblijnej. Znalazło to swój wyraz w obecności tychże dokumentów w książkach i artykułach naukowych, tam gdzie poruszano rozliczne kwestie związane zwłaszcza z kierunkiem studiów nad Biblią, założeniami i efektami stosowania różnych metod badawczych w podejściu do tekstu biblijnego.

Spośród nieżyjących już naukowców wymienić należy przede wszystkim nieodżałowanej pamięci ks. prof. Michała Petera, którego zainteresowania oscylowały wokół prawodawstwa starotestamentowego, Pięcioksięgu oraz historii Izraela, jakkolwiek miał ogromną wiedzę także z zakresu profetyzmu i nurtu mądrościowego. Prace równie wielkiej klasy naukowca, śp. ks. prof. Mariana Wolniewicza, poruszały z kolei głównie rozliczne kwestie Ewangelii i Dziejów Apostolskich, których był wytrawnym znawcą ${ }^{43}$.

${ }^{43}$ Por. m.in. M. Wolniewicz, Święty Józef w Ewangelii, „Ateneum Kapłańskie” 70 (1978) 1, s. 18-31; tenże, Ojczyzna Jezusa. Kraj, ludzie i dzień powszedni, Katowice 1986; tenże, Przypowieści Chrystusowe w Ewangelii św. Mateusza, cz. 1, Poznań 1995, cz. 2, Poznań 1998 (przekład i objaśnienia autora. Publikacja dla dzieci); Nowy Testament Ewangelia wedtug Eukasza, tłum. i oprac. M. Wolniewicz, Poznań 1999; tenże, Ci, którzy byli najblizej. Bliscy Jezusa w Ewangelii, Poznań 1999; tenże, Cuda Jezusa w Ewangelii, „Zeszyty Karmelitańskie” 2 (2002), s. 32-38; tenże, Przyroda w nauczaniu Jezusa, „Zeszyty Karmelitańskie” 4 (2002), s. 53-59; Ewangelia wedtug Marka w przekładzie z greckiego, thum. i oprac. M. Wolniewicz, Poznań 2006; Ewangelia wedlug Mateusza w przekładzie z języka greckiego, tłum. i oprac. M. Wolniewicz, Poznań 2007; Ewangelia wedtug Jana. W przektadzie z języka greckiego, tłum. i oprac. M. Wolniewicz, Poznań 2008. 
Nestor poznańskiej biblistyki, zmarły w roku 2019, ks. prof. Jan Kanty Pytel, specjalizował się zwłaszcza w listach Pawłowych ${ }^{44}$, jakkolwiek zmierzył się również z trudną problematyką apokaliptyczną, co zostało już wyżej zaznaczo$n^{45}$. Żywo interesował się także Romanem Brandstaetterem i propagował pamięć o nim i jego twórczości, będąc przewodniczącym stowarzyszenia imienia tego poety i znawcy Biblii. Pośród celów stowarzyszenia należy wymienić przede wszystkim promowanie i ochronę twórczości pisarza, ale także poznawanie twórców i popularyzację twórczości o charakterze judeochrześcijańskim, nawiązywanie i podtrzymywanie dialogu międzyreligijnego, międzywyznaniowego i międzykulturowego, wieloaspektowe inicjowanie działań kulturalnych na płaszczyznach: literackiej, muzycznej, plastycznej, scenicznej, filmowej, inicjowanie przedsięwzięć i popieranie postaw służących nauce i oświacie, kulturze i sztuce, kulturze języka polskiego, rozwojowi cywilizacyjnemu społeczeństwa polskiego.

Niezwykle wartościowe studia egzegetyczne prowadził także znany w całym kraju, emerytowany pracownik Wydziału Teologicznego, ks. prof. Bogdan Poniży, którego wkład w badania nad Księgą Mądrości jest zdecydowanie największy pośród biblistów polskich. Znakomita większość jego artykułów naukowych dotyczy tej właśnie tematyki, poszerzonej o całość literatury mądrościowej. Specjalizuje się także w szeroko rozumianej teologii Starego Testamentu, której jest znakomitym znawcą ${ }^{46}$. Natomiast były już pracownik Wydziału Teologicznego w Poznaniu, ks. prof. Mieczysław Mikołajczak, zajmował się zwłaszcza teologią świątyni w Nowym Testamencie, chociaż jego zainteresowania naukowe obejmowały szersze spektrum egzegezy i teologii biblijnej. Nie potrzeba dodawać kolejnych wiadomości o dorobku pisarskim o. prof. Sikory, wspomnianym już wcześniej. Obejmuje on kilkanaście pozycji książkowych, ponad 100 artykułów, kilkaset wystąpień popularno-naukowych i kulturalnych w całym kraju ${ }^{47}$.

${ }^{44}$ Por. m.in. J.K. Pytel, List do Filipian, w: Zanim otworzysz Biblię. Praca zbiorowa pod red. Michała Petera (Stary Testament) i Mariana Wolniewicza (Nowy Testament), Poznań 1981, s. 165167; List do Kolosan, w: tamże, s. 167-169; List do Efezjan, w: tamże, s. 169-170; List do Filemona, w: tamże, s. 171; tenże: Studzy Ewangelii w Pierwszym Liście do Koryntian, w: Miłośćjestz Boga. Wokót zagadnień biblijno-moralnych. Studium ofiarowane ks. prof. dr hab. Janowi Łachowi, red. M. Wojciechowski, Warszawa 1997, s. 325-333; tenże, Szawet z Tarsu. Przypatrzcie się, jakie wielkie stawiam litery, (Maneat Quaestio), Poznań 2011.

${ }^{45}$ Całość dorobku Księdza Profesora, por. P. Ostański, Bibliografia prac drukowanych ks. prof. dr hab. Jana Kantego Pytla, w: Verbo Domini servire. Opuscula Ioanni Cantio Pytel septuagenario dedicata, red. F. Lenort, T. Siuda, (Opuscula Dedicata, [t.] 20), Poznań 2000, s. 257-267.

46 Szczegółowy opis dorobku naukowego Księdza Profesora zaleźć można na odpowiednich stronicach Bibliografii Biblistyki Polskiej P. Ostańskiego z lat 1945-1999 oraz 2000-2009 i późniejszych dodatków.

${ }^{47}$ Pełen opis dokonań, por. stronę internetową Wydziału Teologicznego UAM w Poznaniu (teologia.amu.edu.pl). 
Wreszcie nie sposób nie wspomnieć rzeczywiście wielkiego dzieła, chociaż nie ściśle badawczego, za to wymagającego ogromnego poświęcenia i pracowitości, jakiego podjął się ks. dr hab. Piotr Ostański, a którym jest czterotomowa Bibliografia biblistyki polskiej, wydana w Poznaniu: dzieło bez przesady wiekopomne, choćby z tego względu, że jedyne w całościowym zebraniu pisarstwa biblijnego $\mathrm{w}$ naszym $\mathrm{kraju}^{48}$. Wprowadza ona tym samym polskie piśmiennictwo biblijne na salony nauki światowej, czyniąc je wiadomym i pozwalając innym naukowcom ocenić wielkość dorobku rodzimej biblistyki. Stanowi nieocenioną pomoc w poszukiwaniach często zapomnianych już dziś wcześniejszych pozycji naukowych i literackich, lecz także najnowszych prac polskich egzegetów. Również autor niniejszego artykułu obficie korzystał z tej właśnie pozycji, cytując znakomitą większość zawartych tutaj dzieł poszczególnych naukowców środowiska poznańskiego. Młodszej generacji gnieźnieńskim pracownikiem naukowym na Wydziale Teologicznym jest ks. dr hab. Paweł Podeszwa, specjalizujący się w egzegezie i teologii Nowego Testamentu, zwłaszcza tematyce apokaliptycznej, którą zgłębił, przygotowując w roku 2012 rozprawę habilitacyjną ${ }^{49}$. Autor niniejszego artykułu swoje zainteresowania koncentruje wokół Księgi Psalmów, zwłaszcza suplikacyjnych ${ }^{50}$, choć opracował także szerszą tematykę profetyzmu

48 Por. P. Ostański, Bibliografia biblistyki polskiej, t. 1-2: 1945-1999, (Series Bibliographica 1), Poznań 2002. Recenzji pozycji dokonali m.in. ks. prof. W. Chrostowski w „Collectanea Theologica” 73 (2003) 1, s. 221-225 oraz Z.J. Kapera, A guide to Polish Biblical Research, „,The Polish Journal of Biblical Research" 2 (2006), s. 137-144. Kolejną recenzję (Bibliografia biblistyki polskiej, t. 3-4: 2000-2009, [Series Bibliographica 2], Poznań 2010) zamieścił ks. prof. W. Chrostowski w „Collectanea Theologica” 80 (2010) 4, s. 217-220. Całość pracy ukazała się także w formie CD-ROM jako Bibliografia biblistyki polskiej. 1945-2010/2011, Poznań-Robakowo 2011.

${ }^{49} \mathrm{Z}$ artykułów poświęconych Apokalipsie zacytować można: P. Podeszwa, Zobaczyć głos (Ap 1,12). Biblijny postulat języka symbolicznego, w: Język religijny dawniej i dziś (w kontekście teologicznym i kulturowym). Materiały z konferencji, Gniezno, 22-24 września 2008, red. P. Bortkiewicz, S. Mikołajczak, M. Rybka, t. 5, Poznań 2009, s. 199-206; tenże, Zmartwychwstały Chrystus jako nowy Adam (Ap 1,13), w: Memoriale Domini. Księga pamiatkowa dedykowana Księdzu Profesorowi Jerzemu Stefańskiemu w 70. rocznicę urodzin, red. M. Olczyk, W. Radecki, Gniezno 2010, s. 437-452; tenże, ,, To mysterion tou Theou ” (Ap 10,7). Od Księgi Mądrości do Apokalipsy św. Jana, w: Apokaliptyka wczesnego judaizmu i chrześcijaństwa, red. M.S. Wróbel, (Analecta Biblica Lublinensia 6), Lublin 2010, s. 177-194; tenże, Chrystus jako Arcykapłan w świetle J 19,23 oraz Ap 1,13, w: Od Melchizedeka do Jezusa-Arcykapłana. Biblia o kapłaństwie, red. D. Dziadosz, (Analecta Biblica Lublinensia 5), Lublin 2010, s. 193-207; tenże, Dawidowe pochodzenie Jezusa wedlug Apokalipsy Janowej, w: Więcej szczęścia jest w dawaniu aniżeli w braniu. Księga pamiatkowa dla Księdza Profesora Waldemara Chrostowskiego w 60. rocznice urodzin, 3, red. B. Strzałkowska, Warszawa 2011, s. 1229-1246.

${ }^{50}$ Por. J. Nawrot, „Bądź mężny i mocny ponieważ Pan jest z toba”. Andreia i jej motywacja w Biblii greckiej, Poznań 2006, ss. 231; tenże, „Prześladuja biedaka i nieszczęśliwego”. Niegodziwcy wobec sprawiedliwych w psalmach suplikacji, Poznań 2007, ss. 416; tenże, , Ustysz, o Panie, moją modlitwe, odpowiedz mi w swej sprawiedliwości!' 'nh $i$ sm 'wołaniem w zagrożeniu życia w psalmach suplikacji, Poznań 2009, ss. 407. 
na kartach Starego i Nowego Testamentu w ramach pomocy dla studentów ${ }^{51}$. Prowadząc liczne kręgi biblijne, jest zaangażowany zwłaszcza w szerzenie wiadomości o Biblii w wielu parafiach, co stanowi ważny składnik aktywności Uniwersytetu, którego jedną z misji jest popularyzacja osiągnięć naukowych w lokalnym środowisku. Osobno prowadzi także cykl audycji radiowych poświęcony poszczególnym księgom Pisma Świętego ${ }^{52}$.

\section{Przepojenie teologii, kaznodziejstwa, katechezy, homiletyki i wszelkiego nauczania chrześcijańskiego słowem Bożym}

Z kolei ten ważny punkt konstytucji Dei Verbum w poznańskim środowisku naukowym jest realizowany przez pojawienie się także kilku interesujących pozycji wydawniczych, których celem było zainteresowanie czytelników problematyką słowa Bożego i przybliżenie go odbiorcy nieobeznanemu bliżej z arkanami sztuki egzegezy biblijnej. Już w 1969 roku pojawiła się praca zbiorowa pt. Dzieje Bożego Objawienia. Podręcznik do nauki religii, której ks. prof. Peter był współautorem ${ }^{53}$. Książka została zaopatrzona w ilustracje ułatwiające zwłaszcza dzieciom i młodzieży przyswojenie sobie trudnych nieraz perykop biblijnych. Z racji swej popularności doczekała się aż trzech kolejnych wydań w latach 1970-1972. 30 lat później zespół pod redakcją ks. prof. Mariana Wolniewicza wydał ważną pozycję zatytułowaną Biblia. Stary Testament. Wypisy dla szkót ${ }^{54}$. Są to wybrane pod kątem programów szkolnych fragmenty większości ksiąg Starego Testamentu opatrzone komentarzem. Książka stała się cenną pomocą dla uczniów, nauczycieli, a zwłaszcza katechetów. Tekst źródłowy zacytowany został według pełnego wydania tomu Biblii poznańskiej.

Ważne zadanie spełnił także cykl artykułów popularnonaukowych ks. prof. Petera pod wspólnym tytułem Stary Testament od nowa czytany, drukowany w poznańskim „Przewodniku Katolickim” w latach 1961-1967. Podobną pracę podjął kilka lat później śp. ks. prof. Pytel, publikując serię artykułów z ogólnej tematyki biblijnej w miesięczniku „Msza Święta”, redagowanym przez księży chrystusowców w Poznaniu w 1968 roku, z problematyki ściśle nowotestamentowej zaś w „Przewodniku Katolickim” w całym 1971 roku. Odbiorcami było

${ }^{51}$ Por. tenże, Profetyzm pozabiblijny na kartach Starego Testamentu, w: Stary Testament a religie, red. I.S. Ledwoń, Lublin 2009, s. 363-430; tenże, Fatszywi mesjasze — fatszywi prorocy Antychryst, w: Nowy Testament a religie, red. I.S. Ledwoń, Lublin 2011, s. 523-574.

${ }^{52}$ Odbywają się one raz w tygodniu już od kilku lat, a dotychczasowa liczba ich odcinków przekroczyła 200

53 Por. pracę zbiorową Dzieje Bożego Objawienia. Podręcznik do nauki religii, Poznań 1969. Autorzy, m.in.: Michał Peter, Marian Wolniewicz, Jan Pytel.

${ }^{54}$ Por. Biblia. Stary Testament. Wypisy dla szkót, wybór i oprac. M. Wolniewicz, Poznań 1999. 
wówczas szerokie gremium czytelników mniej wprawionych w tajemnice egzegezy, dzięki czemu mogli oni jednak lepiej zrozumieć teologię przekazu staroi nowotestamentowego.

\section{Lektura i staranne studium osobiste Pisma Świętego}

Szerokim echem w środowisku poznańskim odbiła się wydana w roku 1981 pozycja publicystyczno-naukowa „TAK mówi Bóg”. Ogólne wiadomości o Piśmie Świętym, pod red. ks. prof. Petera, ze współautorstwem m.in. księży profesorów Pytla, Wolniewicza i Poniżego. Drugą, równie popularną okazała się Zanim otworzysz Biblię $e^{55}$. Nieco wcześniej (1975) ukazała się monografia samodzielnego autorstwa ks. prof. Petera $W$ kręgu Starego Przymierza. Wprowadzenie do dziejów i teologii Starego Testamentu. Sporym zainteresowaniem cieszył się także cykl artykułów popularnonaukowych ks. prof. Petera Stary Testament od nowa czytany w „Przewodniku Katolickim”, zwłaszcza prehistorii biblijnej, drukowany w latach 1961-1967. Znane są także przypadki współpracy naszych biblistów z innymi ośrodkami naukowymi w kraju, zwłaszcza Warszawy i Lublina.

Kończąc to jubileuszowe podsumowanie dorobku Wydziału Teologicznego wpisującego się w bogactwo form aktywności badawczej, dydaktycznej, połączonej z zaangażowaniem na rzecz wielkopolskiego środowiska społecznego, warto podkreślić, że wymienione wyżej inicjatywy naukowe i popularnonaukowe poznańskiego środowiska naukowego w dziedzinie szeroko pojętej biblistyki stanowią ważny przyczynek do uświetnienia 100-lecia Poznańskiej Wszechnicy Uniwersyteckiej. Obok innych dziedzin nauki mogą z dumą zaprezentować wkład własny w rozwój nauki naszego miasta, lecz także całej nauki polskiej. Można jedynie wyrazić nadzieję, że obecne pokolenie naukowców podejmie pałeczkę przekazaną im w sztafecie pokoleń i dołoży własną cegiełkę w budowę rozwoju naukowego, przyczyniając się do uświetnienia Poznania jako ważnego ośrodka naukowego w Polsce.

${ }^{55}$ Jest to praca zbiorowa pod red. M. Petera (Stary Testament) i M. Wolniewicza (Nowy Testament), wydana przez Księgarnię św. Wojciecha 1981. 


\section{A step further in bringing God's word closer. Poznań Bible scholars in the service of the Old and New Testament messages}

\section{Summary}

On the occasion of 100 years of existence and activity of Adam Mickiewicz University in Poznań, one may sum up the contribution of the Faculty of Theology which has existed as part of the university for 20 years. This contribution has concerned the research and teaching arenas combined with a commitment for the social community of the Wielkopolska province. What is specific of the faculty is its ability to work both on the scientific and didactic levels as well as on the church level, which requires considerable knowledge and time in order to competently combine the requirements of working at university with demands of the Catholic Church managed by the Second Vatican Council. The scientific and popular scientific initiatives in the widely understood biblical studies represent a valuable contribution to the celebration of 100 years of the Poznan university. Like other scientific disciplines, they can proudly make their own contribution to the development of science in our city, as well as the entire country. One can only hope that the present generation of scientists will take the baton passed to them in the relay race of generations, and will make their own contribution to the science thereby honouring Poznań as an important scientific centre in Poland.

\section{Keywords}

Bible scholars, Holy Bible, exegesis, translators, Wielkopolska (Great Poland Region)

\section{Stowa kluczowe}

bibliści, Pismo Święte, egzegeza, tłumacze, Wielkopolska

\section{Bibliografia}

Apokalipsa św. Jana Apostoła, tłum. i komentarz J.K. Pytel, Poznań 2007.

Banaszak M., Profesor Michat Peter (1922-1982), w: F. Lenort, Requinte in libro Domini: Michaeli Peter piae memoriae dedicata, t. 6, Poznań 2005, s. 247-255.

Basiński P., O Verba Sacra, http://www.verbasacra.pl/index.php?option=com_content\&v iew=article\&id=10\&Itemid=2 [dostęp 03.06.2019].

Biblia Hebraica, ed. R. Kittel, P. Kahle, A. Alt, O. Eissfeld, Stuttgart 1951.

Biblia. Stary Testament. Wypisy dla szkót, wybór i oprac. M. Wolniewicz, Poznań 1999.

Chrostowski W., Recenzja P. Ostański, Bibliografia biblistyki polskiej, t. 1-2: 19451999, (Series Bibliographica 1), Poznań 2002, „Collectanea Theologica” 73 (2003) 1, s. $221-225$. 
Chrostowski W., Recenzja P. Ostański, Bibliografia biblistyki polskiej, t. 3-4: 20002009, (Series Bibliographica 2), Poznań 2010 „Collectanea Theologica” 80 (2010) 4, s. $217-220$.

Dzieje Bożego Objawienia. Podręcznik do nauki religii, praca zbiorowa, Poznań 1969.

Ewangelia wedtug Jana. W przekładzie z języka greckiego, tłum. i oprac. M. Wolniewicz, Poznań 2008.

Ewangelia według Marka w przekładzie z greckiego, tłum. i oprac. M. Wolniewicz, Poznań 2006.

Ewangelia wedtug Mateusza w przekładzie z języka greckiego, tłum. i oprac. M. Wolniewicz, Poznań 2007.

Gądecki S., Trudności związane z tłumaczeniem Pisma Świętego na przykładzie 2. Księgi Machabejskiej, „Ziemia Wągrowiecka” 1 (1998), s. 19-28.

Gądecki S., Uwagi do nowego przekładu 1 Mch, „Studia Gnesnensia” 13 (1999), s. 5-6.

Gądecki S., I Księga Machabejska, ,Studia Gnesnensia” 13 (1999), s. 7-51.

Gądecki S., II Księga Machabejska, „Studia Gnesnensia” 13 (1999), s. 53-84.

Grecko-łacińsko-polska synopsa do Pierwszej i Drugiej Księi Machabejskiej, thum. i oprac. S. Gądecki, (Prymasowska Seria Biblijna 19), Warszawa 2002.

Kaczmarski H.J., Biblia Poznańska i inne przekłady Pisma Świętego, „Za i Przeciw” 17 (1976), s. 8.

Kaczmarski H.J., Polskie przekłady Pisma Św. IV. Biblia Poznańska, „Za i Przeciw” 41 (1974), s. 8.

Kaczmarski H.J., Trzytomowa Biblia wydana w Poznaniu, w: Przekłady Pisma Świętego na język polski po II wojnie światowej, „Novum” 4-5 (1977), s. 70-72.

Kapera Z.J., A guide to Polish Biblical Research, „The Polish Journal of Biblical Research" 2 (2006), s. 137-144.

Kierstan J., Przepióra M., Bibliografia prac drukowanych Księdza Profesora Michała Petera, w: Requinte in libro Domini: Michaeli Peter piae memoriae dedicata, red. F. Lenort, t. 6, Poznań 2005, s. 287-300.

Knéga Kapłańskô Leviticus [Księga Kapłańska], z hebrajsczégò jãzëka na kaszëbsczi przełoził ò. Adam Ryszard Sikora OFM, Gduńsk 2017.

Knéga Lëczbów [Księga Liczb], z hebrajsczégò jâzëka na kasëbsczi przełożit ò. Adam Ryszard Sikora OFM, Gduńsk 2018.

Knéga Wińdzeniô: Exodus [Księga Wyjścia], z hebrajsczégò jãzëka na kaszëbsczi przełożił Adam Ryszard Sikora, Gduńsk 2016.

Knéga Zôczątków [Księga Rodzaju], z hebrajsczégò jâzëka na kasëbsczi przełożił ò. Adam Ryszard Sikora OFM, Gduńsk 2015.

Nawrot J., „Bądź mężny i mocny ponieważ Pan jest z toba”. Andreia i jej motywacja w Biblii greckiej, Poznań 2006.

Nawrot J., Fatszywi mesjasze — fatszywi prorocy — Antychryst, w: Nowy Testament a religie, red. I.S. Ledwoń, Lublin 2011, s. 523-574. 
Nawrot J., Kryzys religijny w Judei za Antiocha IV Epifanesa. Teologia historii w 1 Mch 1,1-2,26, (Studia i Materiały 151), Poznań 2012.

Nawrot J., Pierwsza Księga Machabejska. Rozdziały 1,1-6,16, Nowy Komentarz Biblijny. Stary Testament XIV/I, Częstochowa 2016.

Nawrot J., Profetyzm pozabiblijny na kartach Starego Testamentu, w: Stary Testament a religie, red. I.S. Ledwoń, Lublin 2009, s. 363-430.

Nawrot J., „Prześladują biedaka i nieszczęśliwego”. Niegodziwcy wobec sprawiedliwych w psalmach suplikacji, Poznań 2007.

Nawrot J., ,, Ustysz, o Panie, moja modlitwę, odpowiedz mi w swej sprawiedliwości!'” "nh i sm 'wołaniem w zagrożeniu życia w psalmach suplikacji, Poznań 2009.

Nie wstydzę się Ewangelii. Księga Dziejów Apostolskich, red. J.K. Pytel, Szczecin 1999.

Nowy Testament Ewangelia według Łukasza, tłum. i oprac. M. Wolniewicz, Poznań 1999.

Ostański P., Bibliografia biblistyki polskiej, t. 1-2: 1945-1999, (Series Bibliographica 1), Poznań 2002.

Ostański P., Bibliografia prac drukowanych ks. prof. dr hab. Jana Kantego Pytla, w: Verbo Domini servire. Opuscula Ioanni Cantio Pytel septuagenario dedicata, red. F. Lenort, T. Siuda, (Opuscula Dedicata, [t.] 20), Poznań 2000, s. 257-267.

Peter M., Wolniewicz M., Pytel J.K. i in., Dzieje Bożego Objawienia. Podręcznik do nauki religii, Poznań 1969.

Pismo Święte Starego i Nowego Testamentu w przekładzie z języków oryginalnych ze wstępami i komentarzami (Biblia Poznańska), t. 1-3, oprac. zespół pod red. M. Petera (Stary Testament) i M. Wolniewicza (Nowy Testament), słowo wstępne: A. Baraniak, C. Jakubiec, Wprowadzenie w lekturę Pisma Świętego, Poznań 1973-1975.

Podeszwa P., Chrystus jako Arcykapłan w świetle J 19,23 oraz Ap 1,13, w: Od Melchizedeka do Jezusa-Arcykapłana. Biblia o kapłaństwie, red. D. Dziadosz, (Analecta Biblica Lublinensia 5), Lublin 2010, s. 193-207.

Podeszwa P., Dawidowe pochodzenie Jezusa wedtug Apokalipsy Janowej, w: Więcej szczęścia jest $w$ dawaniu aniżeli w braniu. Księga pamiątkowa dla Księdza Profesora Waldemara Chrostowskiego w 60. rocznice urodzin, 3, red. B. Strzałkowska, Warszawa 2011, s. 1229-1246.

Podeszwa P., ,,To mysterion tou Theou ” (Ap 10,7). Od Księgi Mądrości do Apokalipsy św. Jana, w: Apokaliptyka wczesnego judaizmu i chrześcijaństwa, red. M.S. Wróbel, (Analecta Biblica Lublinensia 6), Lublin 2010, s. 177-194.

Podeszwa P., Zmartwychwstaty Chrystus jako nowy Adam (Ap 1,13), w: Memoriale Domini. Księga pamiątkowa dedykowana Księdzu Profesorowi Jerzemu Stefańskiemu w 70. rocznice urodzin, red. M. Olczyk, W. Radecki, Gniezno 2010, s. 437-452.

Podeszwa P., Zobaczyć głos (Ap 1,12). Biblijny postulat języka symbolicznego, w: Język religijny dawniej i dziś (w kontekście teologicznym i kulturowym). Materiaty z konferencji, Gniezno, 22-24 września 2008, red. P. Bortkiewicz, S. Mikołajczak, M. Rybka, t. 5, Poznań 2009, s. 199-206. 
Poniży B., Księga Mądrości. Od egzegezy do teologii, Poznań 2000.

Pytel J.K., List do Efezjan, w: Zanim otworzysz Biblię. Praca zbiorowa pod red. Michała Petera (Stary Testament) i Mariana Wolniewicza (Nowy Testament), Poznań 1981, s. $169-170$.

Pytel J.K., List do Filemona, w: Zanim otworzysz Biblię. Praca zbiorowa pod red. Michała Petera (Stary Testament) i Mariana Wolniewicza (Nowy Testament), Poznań 1981, s. 171.

Pytel J.K., List do Filipian, w: Zanim otworzysz Biblię. Praca zbiorowa pod red. Michała Petera (Stary Testament) i Mariana Wolniewicza (Nowy Testament), Poznań 1981, s. $165-167$.

Pytel J.K., List do Kolosan, w: Zanim otworzysz Biblię. Praca zbiorowa pod red. Michała Petera (Stary Testament) i Mariana Wolniewicza (Nowy Testament), Poznań 1981, s. $167-169$.

Pytel J.K., Studzy Ewangelii w Pierwszym Liście do Koryntian, w: Miłość jest z Boga. Wokół zagadnień biblijno-moralnych. Studium ofiarowane ks. prof. dr. hab. Janowi Łachowi, red. M. Wojciechowski, Warszawa 1997, s. 325-333.

Pytel J.K., Szawet z Tarsu. Przypatrzcie sie, jakie wielkie stawiam litery, (Maneat Quaestio), Poznań 2011.

Pytel J.K., Twarz Biblii Poznańskiej w reflektorze historii, w: Credidimus caritati. Księga pamiatkowa dedykowana Księżom Profesorom Ryszardowi Figlowi i Tadeuszowi Haneltowi w 70. rocznice urodzin, red. M. Olczyk, P. Podeszwa, Gniezno 2010, s. 409-413.

Radwanowa A., W poznańskim środowisku teologicznym. Biblistyka - nauka żywą i aktualna, ,Słowo Powszechne” 178 (1974), s. 6-7.

Scriptura Sacra Posnaniensis. Opuscula Mariano Wolniewicz octogenario dedicata, red. F. Lenort, t. 3, Poznań 2002.

Septuaginta, ed. A. Rahlfs, Stuttgart 1943.

Sikora A.R., Biblia Kaszubska. Verba Sacra w Wejherowie 2004-2008, Wejherowo 2008.

Sikora A.R., Ewangelia wedtug św. Jana na kaszubski ttumaczona. Przekłady z języków niebiblijnych a przekład z języka greckiego, Poznań 2006.

Sikora A.R., Ewanielie na kaszëbsczi tlomaczoné, Gduńsk 2010.

Sikora A.R., Ewanielejó wedle swiategó Jana, Gduńsk 2007.

Sikora A.R., Ewanielejó wedle swiategó Łukasza, Kartuzy 2010.

Sikora A.R., Ewanielejó wedle swiategó Marka, Gduńsk 2001.

Sikora A.R., Ewanielejó wedle swiategó Mateusza, Gduńsk 2009.

Sikora A.R., Komentarz teologiczny i przekład. Księga Psalmów, w: Verba Sacra, Biblia Kaszubska. Księga Psalmów, Wejherowo 2011, s. 3-6, 7-21.

Sikora A.R., Komentarz teologiczny i przekład. Księga Psalmów, w: Verba Sacra, Biblia Kaszubska, Księga Psalmów, cz. II: Psalmy w Nowym Testamencie, Wejherowo 2012, s. 3-6, 8-33.

Sikora A.R., Nowi Testameńt. Ewanielie pò kaszëbskù, Gduńsk 2014². 
Sikora A.R., Teksty biblijne w najstarszych zabytkach piśmiennictwa kaszubskiego (XVIXVIII w.), Poznan 2009.

Sikora A.R., Zestawienié synopticzné szterzech Ewanielii na kaszëbsczi tolmaczonëch, Poznań 2014.

Smereka W., Biblia Poznańska. Nowy przekład Pisma Św, „Gość Niedzielny” 23 (1974), s. $178-180$.

Smereka W., Biblia Poznańska (O nowym polskim przekładzie Pisma Świętego), „Tygodnik Powszechny" 20 (1974), s. 7.

Smereka W., Nowy przekład z pożytecznym komentarzem, „Przegląd Katolicki” 20 (1975), s. 11.

Stanek T., Ksiegga Habakuka. Przestanie i przeklad filologiczny na podstawie tekstu masoreckiego, w: Requirite in Libro Domini. Opuscula Michaeli Peter piae memoriae dedicata, red. F. Lenort, (Opuscula Dedicata 6), Poznań 2005, s. 97-110.

Stanek T., Ksiega Rut: Propozycja nowego przektadu na podstaw masoreckiego, „Poznańskie Studia Teologiczne" 15 (2003), s. 9-29.

Szczepaniak M., Abp Gadecki promuje Dzieło Biblijne, 1 grudnia 2006, [online] http:// info.wiara.pl/doc/162912.Abp-Gadecki-promuje-Dzielo-Biblijne [dostęp 4.06.2019].

Szuba Z., Zakończenie edycji Biblii Poznańskiej, „Słowo Powszechne” 71 (1976), s. 7.

„TAK mówi Bóg”. Ogólne wiadomości o Piśmie Świętym, red. M. Peter, J.K. Pytel, M. Wolniewicz, B. Poniży i in., Poznań 1981.

The Greek New Testament, ed. K. Aland, M. Black, B.M. Metzger, A. Wikgren, Stuttgart $1968^{2}$.

Turian [J. Turnau], Mamy nowa Biblię, „Więź” 9 (1976), s. 26-31.

Węcławski T., Dobra nowina wedlug świętego Marka, Poznań 1999.

Węcławski T., Ewangelia dla dzieci, Kraków $2006^{2}$.

Wolniewicz M., Ci, którzy byli najblizej. Bliscy Jezusa w Ewangelii, Poznań 1999.

Wolniewicz M., Cuda Jezusa w Ewangelii, „Zeszyty Karmelitańskie” 2 (2002), s. 32-38.

Wolniewicz M., Ojczyzna Jezusa. Kraj, ludzie i dzień powszedni, Katowice 1986.

Wolniewicz M., Przypowieści Chrystusowe w Ewangelii św. Mateusza, cz. 1, Poznań 1995, cz. 2, Poznań 1998.

Wolniewicz M., Przyroda w nauczaniu Jezusa, „Zeszyty Karmelitańskie” 4 (2002), s. 53-59.

Wolniewicz M., Święty Józef w Ewangelii, „Ateneum Kapłańskie” 70 (1978) 1, s. 18-31.

Zanim otworzysz Biblię, red. M. Peter (Stary Testament), M. Wolniewicz (Nowy Testament), Poznań 1981.

Zaradniak M., Dzień Judaizmu w Poznaniu 2019. Nie przyszedlem, aby zatracać. Poznaj kulture żydowska, 11 stycznia 2019 [online] https://gloswielkopolski.pl/dzien-judaizmu-w-poznaniu-2019-nie-przyszedlem-aby-zatracac-poznaj-kulture-zydowska/ $\operatorname{ar} / 13800031$ [dostęp 3.06.2019]. 
Strony internetowe

biblista.pl

coexist.pl

teologia.amu.edu.pl 